\title{
BERN RADIOCARBON DATES I
}

\author{
H. OESCHGER, U. SCHWARZ, CHR. GFELLER
}

\section{Physikalisches Institut, Universität Bern}

This list covers the measurements made at the University of Bern up until summer 1958. The low-level apparatus is described by Houtermans and Oeschger (1958).

The samples are converted into acetylene and measured at a pressure of nearly 1 atmosphere. Peat samples have been pretreated by washing with hot dilute hydrochloric acid. Bone samples have been charred before the treatment with acid. As modern reference standard the mean radiocarbon content of several wood samples, formed between A.D. 1850 and 1900, has been used. The errors given are the standard deviations derived from the number of counted particles and the statistical errors of background and standard.

If no significant net effect differing by $>2 \sigma$ from background has been measured, the minimum age has been calculated from the background plus $2 \sigma$.

The list is divided into two groups. The first consists chiefly of samples related to the history of vegetation in the northern and southern Swiss Alps, the second of archaeologic samples, mainly from lake dwellings.

\section{ACKNOWLEDGMENTS}

This work was made possible by a grant of the "Schweizerischer Nationalfonds". The authors wish to thank F. G. Houtermans for having suggested the dating equipment, which they have used for the measurements described. They are indebted also to W. Buser and P. Graf who have contributed to the chemical apparatus, and to H. Schlapbach and A. Forster for the preparation of the samples. Furthermore, they thank M. Welten and H. G. Bandi for their help in selecting and discussing the samples.

\section{SAMPLE DESCRIPTIONS}

\section{QUATERNARY GEOLOGY AND VEGETATIONAL HISTORY}

\section{Schynige Platte series, Switzerland}

This series gives the age and the rate of formation of a $40 . \mathrm{cm}$ layer of humus in a podzol profile in the alpine zone near the recent forest border at Schynige Platte, Bernese-Alps $\left(46^{\circ} 39^{\prime} 8^{\prime \prime} \mathrm{N}\right.$ Lat, $7^{\circ} 54^{\prime} 41^{\prime \prime} \mathrm{E}$ Long $)$, alt. $1880 \mathrm{~m}$. Coll. July 1954 and subm. by Max Welten, University of Bern. Comment: larger roots were removed from sample. Results agree with palynological data (Welten, 1958a). In contrast to the result of B-57 $(3670 \pm 100$; this paper), the humus at this locality began to form during Sub-Atlantic time, and its raw upper portion is less than a thousand years old. The series demonstrates the importance of radiocarbon dating for pedology.

B-11. Schynige Platte 2

Alpine humus (Mor, sensu Kubiena) ; deepest part of black humus layer, just ahove bleached layer of an alpine podzol profile, $36 \mathrm{~cm}$ below surface. 
B-12. Schynige Platte 1

$770 \pm 130$

Alpine ericaceous raw humus; deepest part of the undestroyed raw humus layer, $19 \mathrm{~cm}$ below surface.

B-13. Schynige Platte 3

$440 \pm 120$

Loose brown raw humus (Mull, sensu Kubiena) ; $3 \mathrm{~cm}$ below surface.

\section{Schruns series, Vorarlberg, Austria}

Samples from trunks buried by a landslide, near Rätikon $\left(47^{\circ} 5^{\prime} 6^{\prime \prime} \mathrm{N}\right.$ Lat, $9^{\circ} 54^{\prime} 48^{\prime \prime}$ E Long), alt. $1700 \mathrm{~m}$. The wood was found at an underground depth of $70 \mathrm{~m}$. Subm. December 1954 by Vorarlberger Illwerke AG., Schruns. Comment: another wood sample from this landslide was dated by the Heidelberg laboratory (H 122-100, $5860 \pm 150$; Münnich, 1957).

\section{B-17. Illwerke I}

Pine wood

B-18. Illwerke II

Pine wood

B-19. Illwerke $\mathbf{X}$

Maple wood
$5350 \pm 140$

$5500 \pm 160$

$\mathbf{5 5 0 0} \pm \mathbf{1 4 0}$

$3200 \pm 130$

\section{B-30. St. Gallen, Switzerland}

Fir with mistletoe, subm. as interlaboratory check on Heidelberg's sample H 81-62 (Münnich, 1957). Comment: Heidelberg's data was $3040 \pm 100$.

\section{Murifeld series, Bern, Switzerland}

Gyttja and peat from a lake and bog deposit, Murifeld, near Bern $\left(7^{\circ} 28^{\prime}\right.$ $35^{\prime \prime}$ E Long, 46 $56^{\prime} 22^{\prime \prime} \mathrm{N}$ Lat). Nine borings were made within a small area, and the samples from particular layers were fused. Levels I and II, the oldest, were too inorganic for dating. Coll. April 1952 and subm. by Max Welten, University of Bern. Comment: B-38 is the first measurement of an Allerød layer in the Alps. The age of the next sample, B-42, seems anomalously young, but the reason for this is not known. B-36 is acceptable. The difference between the two youngest samples, B-34 and B-37, is not significant, hence their inverse order is meaningless; the rate of sedimentation was very rapid in this part of the profile. Together they fix the beginning of hazel-pollen time at about 6000 B.c.; definitely younger than in western and northern Europe (7000 B.C.). There is no doubt that this difference is valid for our region; see B-77, B-56, B-72, and B-83 (this paper).

B-38. Murifeld III

$10,950 \pm 250$ zone.

Gyttja with clay, very little chalk, depth $412.5 \mathrm{~cm}$, upper part of Allerød

\section{B-42. Murifeld IV}

$10,100 \pm 210$

Gyttja with clay and chalk, depth $405 \mathrm{~cm}$, lower part of Pinus-forest zone.

B-36. Murifeld V

$9250 \pm 160$

Detritus-gyttja, just above chalk-gyttja, depth $291.5 \mathrm{~cm}$, upper part of Pinus-forest zone. 
B-34. Murifeld IV

$8070 \pm 135$

Sedge-peat, depth $185 \mathrm{~cm}$, bottom of Corylus zone.

B-37. Murifeld VII

$8150 \pm 180$

Sedge-peat, depth $166 \mathrm{~cm}$, near bottom of Corylus zone.

\section{Egelsee series, Switzerland}

Peat and gyttja from a pollen-dated section (Welten, 1952), near Diemtigen, Simmental, Bernese Oberland $\left(7^{\circ} 32^{\prime} 35^{\prime \prime} \mathrm{E}\right.$ Long, $46^{\circ} 39^{\prime} 0^{\prime \prime} \mathrm{N}$ Lat $)$, alt. $1000 \mathrm{~m}$. Coll. October 1950 and subm. by Max Welten, University of Bern. Comment: in order to have sufficient carbon it was necessary to add some material from above and below the indicated depth. In the middle part of this profile there are some uncertainties and there may be serious mistakes. Recent work has shown that the ground of the basin has sunk abruptly as a consequence of solution of gypsum of Triassic age, thereby probably disturbing some of the overlying organic material. The beginning of Abies time should have been younger than the date of B-55. For palynological results, see Welten (1952).

B-50. Egelsee $144.1 \mathrm{~cm}$

$1790 \pm 120$

Sphagnum peat, depth $144.1 \mathrm{~cm}$; approximately Roman time.

B-51. Egelsee $355 \mathrm{~cm} \quad 3530 \pm 160$ Detritus-gyttja, depth $355 \mathrm{~cm}$; Abies and Picea have nearly equal values.

B-52. Egelsee $598 \mathrm{~cm}$

$4400 \pm 160$ Sphagnum-rich detritus-gyttja, depth $598 \mathrm{~cm}$; fall of Abies, rise of Picea.

B-53. Egelsee $694.5 \mathrm{~cm}$

$4920 \pm 130$

Sphagnum-rich detritus-gyttja, depth $694.5 \mathrm{~cm}$; end of Abies dominance.

B-55. Egelsee $903 \mathrm{~cm}$

$6850 \pm 175$

Gyttja and mud, depth $903 \mathrm{~cm}$; beginning of Abies-rich Quercetummixtum phase.

B-56. Egelsee $938.8 \mathrm{~cm}$

$7550 \pm 175$

Gyttja and mud, depth $938.8 \mathrm{~cm}$ below surface; towards the end of the Corylus phase.

\section{B-57. Hohgant, Steinige Matte, Switzerland}

$3670 \pm 100$

Raw humus of alpine dwarf scrub (esp. Loiseleuria), 12 to $13 \mathrm{~cm}$ below surface, from Hohgant, Steinige Matte, North-Alps $\left(46^{\circ} 47^{\prime} 7^{\prime \prime} \mathrm{N}\right.$ Lat, $7^{\circ} 53^{\prime}$ $53^{\prime \prime}$ E Long), alt. 2140 m. Coll. August 1956 and subm. by Max Welten, University of Bern. Comment: the beginning of formation of raw humus is in full agreement with palynological dating (Welten, 1958a, p. 269) : about 2000 B.c., when the borderline of the forest had risen to the neighborhood of the locality. Compare B-11, B-12, B-13 (this paper).

B-59. Hohgant, Blockhaus-Bröndlisfluh, Switzerland $320 \pm 110$ Sedge-peat from Hohgant, Blockhaus-Bröndlisfluh, North-Alps $\left(46^{\circ} 47^{\prime}\right.$ $3^{\prime \prime}$ N Lat, $7^{\circ} 54^{\prime} 29^{\prime \prime}$ E Long), alt. $1780 \mathrm{~m}$. Coll. 1956 by O. Hegg; subm. by Max Welten and S. Wegmüller, University of Bern. Comment: the age agrees 
with the general view that the extension of Pinus mugo near present treeline is fairly recent (Wegmüller, in press).

\section{Bitsch-Naters series, Switzerland}

Gyttja and peat from Bitsch-Naters, Wallis, near Brig $\left(46^{\circ} 20^{\prime} 24^{\prime \prime} \mathrm{N}\right.$ Lat, $7^{\circ} 59^{\prime} 26^{\prime \prime}$ E Long), alt. $1030 \mathrm{~m}$. Coll. September 1956 by Max Welten and O. Hegg; subm. by Welten, University of Bern. Comment: the date of the lower sample has much interest in connection with other similar dates for the retreat of the Aletsch-glacier from the main valley of the Rhone. Other determinations have been made in this interesting palynological profile (Welten, $1958 \mathrm{~b}$ ).

B-72. Bitsch-Naters III, $584 \mathrm{~cm}$

Gyttja, near bottom of profile, formation of which began after the retreat of the Aletsch-glacier.

B-73. Bitsch-Naters III, $365 \mathrm{~cm}$

$2600 \pm 100$

Bottom of peat, dating the time when the surface of the little lake was invaded by sedges.

\section{B-75. Boltigen, Chutti, Switzerland}

$11,230 \pm 380$

Cyttja at $565 \mathrm{~cm}$ depth between clay and chalk from Boltigen, Chutti, Simmental, Bernese Oberland $\left(46^{\circ} 38^{\prime} 10^{\prime \prime} \mathrm{N}\right.$ Lat, $7^{\circ} 23^{\prime} 42^{\prime \prime}$ E Long), alt. $925 \mathrm{~m}$. The pollen diagram was published by Welten (1952, p. 36). Coll. March 1957 and subm. by Max Welten, University of Bern. Comment: this and B-38 (10,950 \pm 250 , this paper $)$ are the first radiocarbon dates for Allerød layers in the Alps. Stratigraphy and dating agree fully with Northern Europe.

\section{B-77. Montana Xires, Switzerland}

$\mathbf{7 8 7 0} \pm \mathbf{2 4 0}$

Gyttja, in part chalky, from $314 \mathrm{~cm}$ depth at Montana Xirès, Wallis $\left(46^{\circ}\right.$ $18^{\prime} 28^{\prime \prime} \mathrm{N}$ Lat, $7^{\circ} 28^{\prime} 20^{\prime \prime} \mathrm{E}$ Long), alt. $1445 \mathrm{~m}$ in the warm and continental part of Kanton Wallis. Coll. September 1956 by Max Welten and J. Liechti; subm. by Welten, University of Bern. Comment: the date agrees with B-34, B-37, B-56, B-72, and B-83 (this paper) in showing that the rise of the Corylus-curve in this part of the Alps took place about 6000 B.c. (Welten, 1958b). This agreement proves that chalky gyttja is not necessarily unsuitable for radiocarbon dating. This date has no direct connection with the retreat of the Rhone glacier.

\section{Aletschwald series, Switzerland}

Gyttja and peat from Aletschwald Natural Reserve, Wallis $146^{\circ} 23^{\prime} 14^{\prime \prime}$ N Lat, $08^{\circ} 01^{\prime} 15^{\prime \prime}$ E Long), alt. $2010 \mathrm{~m}$, very close to Aletsch-glacier, the longest-existing glacier in the Alps. Coll. September 1956 by Max Welten and B. Seddon; subm. by Welten, University of Bern. Comment: all dates are from a single peat profile in a bog formed behind a ridge of rock. All except B-80 form a consistent and reasonable series, dating the whole vegetational development since a late Würm-stage of the glacier's lateral retreat to a lower altitude in the axis of the valley. Details have been discussed elsewhere (Welten, $1958 \mathrm{~b})$. The one anomalous date cannot be explained either by disturbance of the peat at this level or by laboratory error. 
B-78. Aletschwald $410 \mathrm{~cm}$

$6140 \pm 150$

Clay-gyttja

B-79. Aletschwald $376 \mathrm{~cm}$

$5610 \pm 130$

Gyttja and sedge-peat

B-112. Aletschwald $330 \mathrm{~cm}$

$4700 \pm 180$

Sedge- and Hypnaceae peat

B-80. Aletschwald $280 \mathrm{~cm}$

$5570 \pm 130$

Sedge- and Hypnaceae peat

B-113. Aletschwald $230 \mathrm{~cm}$

$4000 \pm 100$

Sedge- and Hypnaceae peat

B-81. Aletschwald $180 \mathrm{~cm}$

$3270 \pm 130$

Sedge- and Hypnaceae peat

B-82. Aletschwald $40 \mathrm{~cm}$

Sedge- and Hypnaceae peat

$960 \pm 190$

\section{Lac du Mont d'Orge series, Switzerland}

Gyttja mixed with clay and chalk from Lac du Mont d'Orge, near Sion, Wallis ( $46^{\circ} 14^{\prime} 8^{\prime \prime} \mathrm{N}$ Lat, $7^{\circ} 20^{\prime} 25^{\prime \prime}$ E Long), alt. $640 \mathrm{~m}$. Coll. September 1956 by Max Welten and J. Liechti; subm. by Welten, University of Bern. Comment: the date of the deeper sample agrees well with B-34, B-37, B-56, B- 72 , and B-77 in placing the rise of hazel at about 6000 B.C. Further determinations will elucidate the vegetational history of this interesting inner-alpine valley with its continental climate and its characteristic pine-forest vegetation. Within the relatively uniform pollen diagram radiocarbon dating is the only means of dating minor oscillations. A preliminary note has been published by Welten (1958b).

B-83. Lac du Mont d'Orge III

$7730 \pm 240$

$1304 \mathrm{~cm}$

\section{B-84. Lac du Mont d'Orge III}

$5650 \pm 150$

$1184 \mathrm{~cm}$

\section{La Trelasse series, Switzerland}

Peat in a well-developed Sphagnum bog at La Trélasse, near St. Cergue $\left(46^{\circ} 27^{\prime} \mathrm{N}\right.$ Lat, $6^{\circ} 7^{\prime} \mathrm{E}$ Long), western part of Jura mountains, alt. $1242 \mathrm{~m}$. Coll. October 1956 by S. Wegmüller and Max Welten; subm. by Welten, University of Bern. Comment: these samples date the invasion of Abies and Picea in the western Jura chain. Further determinations are planned.
B-87. La Trelasse $190 \mathrm{~cm}$
$2950 \pm 110$
B-88. La Trelasse $340 \mathrm{~cm}$
$5310 \pm 100$

\section{Tongrube Albishof series, Switzerland}

Wood (Pinus cf. silvestris) from Tongrube Albishof, Zürich, at the foot of the little mountain Uto $\left(47^{\circ} 23^{\prime} \mathrm{N}\right.$ Lat, $8^{\circ} 29^{\prime}$ E Long $)$, alt. $450 \mathrm{~m}$. Sample 1 was taken at $22 \mathrm{~m}$ below surface, sample 2 at $3.5 \mathrm{~m}$ below surface in a large 
clay pit. Coll. 1956 and subm. by Werner Lüdi, Geobotanisches Institut Rübel, Zürich. Comment: the huge mass of clay, $30 \mathrm{~m}$ thick, was not covered by moraine and was therefore known to be postglacial, but as it lies outside the limits of the latest glacial advances it was assumed (Lüdi, 1934) to have washed down the Uto in late-glacial time. The two dates fail to support this belief, as does the fact that the trees were pine, and show that the mass of clay was deposited in Boreal and early Atlantic time. A pine forest that lasted until 4800 B.c. at this locality must have been a relict. On the other hand, so late a date for massive slopewash has interesting climatic implications.

B-90. Tongrube Albishof $1,22 \mathrm{~m}$

$$
8700 \pm 220
$$

B-91. Tongrube Albishof $2,3.5 \mathrm{~m}$

$6850 \pm 100$

\section{Aletschgletscher series, Switzerland}

Wood samples from Aletschgletscher, Switzerland, Canton Wallis, Southern Granite-Gneiss and Transition zone of the Aare Massif. The trees, rooted on bedrock, were killed by an extension of the glacier and recently uncovered by its retreat (Röthlisberger and Oeschger, in press).

\section{B-32. Aletschgletscher I}

$720 \pm 100$

Larch from "Grosser Aletschgletscher", right side of the tongue, on the E slope of the rock ridge $\left(46^{\circ} 23^{\prime} 35^{\prime \prime} \mathrm{N}\right.$ Lat, $8^{\circ} 00^{\prime} 40^{\prime \prime}$ E Long). Coll. July 1956 and subm. by H. Röthlisberger, in 1956 with ETH, Zürich, now with SIPRE.

\section{B-7 1. Aletschgletscher II}

$800 \pm 100$

Deciduous (bush?) from "Grosser Aletschgletscher", right side, at the foot of Obfluheggen rock ridge $\left(46^{\circ} 23^{\prime} 59^{\prime \prime} \mathrm{N}\right.$ Lat, $8^{\circ} 01^{\prime} 03^{\prime \prime} \mathrm{E}$ Long). Coll. September 1956 and subm. by H. Röthlisberger.

B-66. Winterthur, Switzerland

$1120 \pm 100$

Peat containing some gravel from Winterthur $\left(47^{\circ} 30^{\prime} \mathrm{N}\right.$ Lat, $8^{\circ} 44^{\prime} \mathrm{E}$ Long), alt. 440 m. Coll. 1956 and subm. by Werner Lüdi, Geobotanisches Institut Rübel, Zürich. Comment: the peat seems to be quite young and the moraine-like material that overlies it has evidently been displaced into secondary position. Hence the sample is not interglacial, as was supposed (Lüdi, unpublished).

\section{B-67. Freienbach, Switzerland}

$4670 \pm 95$

Oak wood, imbedded in moraine-like material at Freienbach, near Pfäffikon ( $47^{\circ} 12^{\prime} \mathrm{N}$ Lat, $8^{\circ} 46^{\prime} \mathrm{E}$ Long), outside of the Hurden moraine, alt. $420 \mathrm{~m}$. Coll. 1956 and subm. by Werner Lüdi, Geobotanisches Institut Rübel, Zürich. Comment: the inclosing material seems, from the date of the wood, either not to be till or not to be in primary position, and the date is therefore of local interest only.

\section{B-20. Glütschtal, Switzerland}

Lignite (Schieferkohle) from Glütschtal, near Thun, Bernese Oberland ( $46^{\circ} 43^{\prime} \mathrm{N}$ Lat, $7^{\circ} 36^{\prime} \mathrm{E}$ Long), alt. ca. $600 \mathrm{~m}$. Coll. 1938 and subm. by $\mathrm{P}$. Beck, teacher and geologist, Thun. Comment: the age of this lignite, and of 
similar deposits at Hurifluh and Wässerifluh, has been disputed (Gerber, 1923; Beck, 1938; Lüdi, 1953). The date supports Beck's assignment to the Würm I/Il interstadial, but the other deposits are not necessarily of the same age.

\section{B-29. Gondiswil-Zell, Switzerland}

Lignite (Schieferkohle) from Gondiswil-Zell, Kt. Luzern, between Huttwil and Willisau ( $47^{\circ} 8^{\prime} \mathrm{N}$ Lat, $7^{\circ} 55^{\prime} \mathrm{E}$ Long). Stratigraphy details are given by Rytz (1923). Coll. 1940-1945 and subm. by P. Beck, teacher and geologist, Thun. Comment: the most probable stratigraphic assignment, according to the collector, is to the Riss-Würm interglacial age. The date excludes the possibilities of various interstadial ages within Würm time, which were regarded as unlikely before, but does not exclude a Mindel-Riss or an early Würm-interstadial age.

\section{B-33. Varese, Italy}

Lignite (Schieferkohle) from Valle della Fornace near Varese, northern Italy (approx. $45^{\circ} 50^{\prime} \mathrm{N}$ Lat, $8^{\circ} 50^{\prime} \mathrm{E}$ Long). Coll. and subm. by P. Beck, geologist, Thun. Comment: the lignites were supposed to be of Günz age by Nangeroni, of Mindel-Riss interglacial age by Beck (1938). Since the sample showed no measurable activity, a young age is excluded, but radiocarbon dating cannot decide between the two more probable ages.

\section{B-68. Küssnacht, Switzerland}

Peaty lignite from Küssnacht am Rigi, Vierwaldstättersee $\left(47^{\circ} 5^{\prime} \mathrm{N}\right.$ Lat, $8^{\circ} 27^{\prime} \mathrm{E}$ Long), alt. $470 \mathrm{~m}$. The sample was taken from the deeper of two layers of lignite which were separated by 2 to $3 \mathrm{~m}$ of sand. Beneath and above these two layers there are layers of gravel clearly of glacial origin. The lower layer was $30 \mathrm{~cm}$, the upper layer $100 \mathrm{~cm}$, at the section sampled. Coll. April 1949 and subm. by Werner Lüdi, Geobotanisches Institut Rübel, Zürich. Comment: the date confirms Lüdi's view (1953) that a younger Würm interstadial age is unlikely, but leaves open the choice between an older Würm interstadial and an interglacial age.

\section{B-69. Mörschwil, Switzerland}

Lignitized wood from a lignite deposit at Mörschwil, near St. Gallen $\left(47^{\circ}\right.$ $28^{\prime}$ N Lat, $9^{\circ} 25^{\prime}$ E Long), alt. 500 m. Coll. May 1945 and subm. by Werner Lüdi, Geobotanisches Institut Rübel, Zürich. Comment: the limit of age is stated conservatively for instrumental reasons, but the age is believed to be "infinite". Geologic dating makes a Riss-Würm interglacial age more likely than one in the Würm I/II interstadial, but the radiocarbon date fails to prove this.

\section{B-92. Sulzberg, Baden, Switzerland}

Wood from the uppermost part of the so-called lignite, which seems loose, from Sulzberg, E of Baden-Wettingen $\left(47^{\circ} 28^{\prime} \mathrm{N}\right.$ Lat, $8^{\circ} 20^{\prime} \mathrm{E}$ Long), alt. $490 \mathrm{~m}$. Coll. August 1957 and subm. by Max Welten, University of Bern. Comment: the lignite has been thought to be of Riss-Würm interglacial age (Lüdi, 1953). Our determination of age means that the upper part of the peat has been formed within the last Würm-stadial. It may well be that the lower part 
belongs to the beginning of the long Würm-interstadial. Further determinations of age are necessary.

\section{B-8. Vindonissa, Switzerland}

$1930 \pm 80$

Piece of wood from dust-heap in the Roman settlement of Vindonissa (modern Windisch) near Brugg $\left(47^{\circ} 29^{\prime} \mathrm{N}\right.$ Lat, $8^{\circ} 13^{\prime}$ E Long). Subm. by H. G. Bandi, Historisches Museum, Bern. Comment: the age agrees with the archaeologic data, which fix the sample as probably from the second half of the first century, not before A.D. 17 and not later than A.D. 101.

\section{B-16. Seeberg-Fürsteiner, Switzerland}

$10,200 \pm 200$

Log (Pinus silvetris?), $35 \mathrm{~cm}$ long, from Burgäschisee, near Seeberg, Kanton Bern ( $47^{\circ} 11^{\prime} \mathrm{N}$ Lat, $7^{\circ} 39^{\prime} 40^{\prime \prime} \mathrm{E}$ Long). The epipalaeolithic culture layer lies in sandy peat or compressed gyttja, overlying outwash gravel of Würm-retreat and overlain by postglacial lake sediments. The site is in the area covered by the Rhone glacier during the Würm age. Archaeologically (Bandi, 1952; Wyss, 1953), it is just in a transition between Palaeolithic and Mesolithic, with no microliths. Coll. and subm. by H. G. Bandi, Historisches Museum, Bern. Comment: this sample has also been dated by the Pisa laboratory as Pi-6, 10,178 \pm 400 (Ferrara, Reinharz, and Tongiorgi, 1959).

\section{Thayingen series, Switzerland}

Wood from a construction by lake-dwelling people (better: bog-dwelling) (Guyan, 1955) at Thayingen, near Schaffhausen $\left(47^{\circ} 45^{\prime} \mathrm{N}\right.$ Lat, $8^{\circ} 42^{\prime} \mathrm{E}$ Long), alt. $460 \mathrm{~m}$. Coll. 1956 by J. Troels-Smith, National Museum, Copenhagen; subm. by Max Welten, Iniversity of Bern.

\section{B-43. Thayingen Wh-158 \\ Wood of Alnus}

$$
\begin{aligned}
& 4690 \pm 130 \\
& 4690 \pm 180 \\
& 4780 \pm 130
\end{aligned}
$$

B-44. Thayingen Wh-161

Wood of oak

Comment: the first sample (B-43) corresponds to a slightly older archaeologic age than the others, but the difference is not detectable by radiocarbon. A similar sample was dated at Groningen (unnumbered, $4735 \pm 130$; de Vries and Barendsen, 1954). Samples Wh-158 and Wh-149 have also been dated at Copenhagen (Tauber, unpublished), and gave $4560 \pm 140$ and $4380 \pm 140$, respectively.

\section{Secherg Burgäschisece-Siid series, Switzerland}

Wood, charcoal, and bone from a settlement of the Younger Cortaillod culture, inhabited near the end of the Vollneolithikum (Full Neolithic) of Switzerland at Burgäschisee, near Seeberg, Kanton Bern $\left(47^{\circ} 11^{\prime} \mathrm{N}\right.$ Lat, $7^{\circ}$ $40^{\prime} \mathrm{E}$ Long). The samples were taken from a peatlike but man-made layer, 5 to $60 \mathrm{~cm}$ thick, between layers of lake sediments (lake-marl). Coll. by $\mathrm{H}$. Müller-Beck; subm. by H. G. Bandi, Historisches Museum, Bern. 
B-114. Seeberg Burgäschisee-Süd 1

Charcoal, coll. Octoler 1957, from charcoal layer below a thin zone of loam, overlying a sequence of loam and charcoal layers.

B-115. Seeberg Burgäschisee-Suid 2

Post-wood (Quercus), Post 199, taken $22 \mathrm{~cm}$ below the culture layer in the lower lake-marl. Coll. October 1957.

B-116. Seeberg Burgäschisee-Süd 3 Average: $1840 \pm 110$

Wood from a crudely made board (Quercus) in meter-quadrat $33 \mathrm{~A}$, with the following stratigraphy: Modern soil, $30 \mathrm{~cm}$; peat-gyttja, $10 \mathrm{~cm}$; lake-marl, $15 \mathrm{~cm}$; man-made sediment, $15 \mathrm{~cm}$; board, lake-marl. Coll. October 1957.

B-118A. Seeberg Burgäschisee-Süd 5A

$4490 \pm 90$

Wood mixture of small fragments from the culture layer. Coll. in meterquadrat 34 A, November 1957, with the following stratigraphy: modern soil, $30 \mathrm{~cm}$; peat-gyttja, $10 \mathrm{~cm}$; lake-marl, $15 \mathrm{~cm}$; man-made layer, 10 to $17 \mathrm{~cm}$, lake-marl. Sample taken from the upper third of the man-made layer.

B-118B. Seeberg Burgäschisee-Süd 5B $\quad 4630 \pm 180$

Bone material (small fragments) from the culture layer. Coll. in meterquadrat 34 A, November 1958; stratigraphy as for B-118A. Sample was taken from the upper third of the culture layer. Comment: there appears to have been almost no exchange of carbonates (such as occurs regularly in cave sediments).

B-119A. Seeberg Burgäschisee-Süd 6A

$1750 \pm 100$

Wood (mixture of small fragments) from the culture layer. Coll. in meterquadrat 34 A, November 1958; stratigraphy as for B-118A. Sample taken from the lower third of the culture layer.

B-119B. Seeberg Burgäschisee-Süd 6B

$4800 \pm 130$

Bone material (small fragments) from the culture layer. Coll. in meterquadrat 34. A. November 1958; stratigraphy as for B-118A. Sample taken from the lower third of the culture layer. Comment: this pair also shows essentially no diagenetic exchange of carbonates; see B-118A and B.

B-120. Seeberg Burgäschisee-Siid 7

$4500 \pm 100$

Wood (soft wood) from Post 03. Coll. November 1957. The sample was taken $30 \mathrm{~cm}$ below the culture layer in the lower lake-marl.

B-121. Seeberg Burgäschisee-Süd 8

$4680 \pm 100$

Wood (Quercus) from Post 135. Coll. November 1957. The sample was taken $35 \mathrm{~cm}$ below the culture layer in the lower lake-marl.

B-122. Seeberg Burgäschisee-Siid 9

$1750 \pm 100$

Wood (Abies?) from Post 146. Coll. November 1957. The sample was taken $40 \mathrm{~cm}$ below the culture layer in the lower lake-marl.

B-123. Seeberg Burgäschisee-Süd 10

$4530 \pm 100$

Wood (Quercus), coll. November 1957. The sample was taken $45 \mathrm{~cm}$ below the culture layer in the lower lake-marl. 
B-124. Seeberg Burgäschisee-Süd 11

$130 \pm 80$

Post-wood (Picea), coll. November 1957. The sample was taken just above the culture layer. Comment: this was a marker stake of the 1952 excavation and shows the Suess effect in being older than our modern reference standard.

B-125. Seeberg Burgäschisee-Süd $12 \quad 4550 \pm 100$

Wood (Quercus) from Post 962. Coll. November 1957. The sample was taken $30 \mathrm{~cm}$ below the culture layer in the lower lake-marl. Comment: this post, from the western part of House I, was made from the same tree as Post 977, sample B-126.

\section{B-126. Seeberg Burgäschisee-Süd 13}

$4500 \pm 110$

Wood (Quercus) from Post 977, coll. November 1957. The sample was taken $35 \mathrm{~cm}$ below the culture layer in the lower lake-marl. Comment: this post, also from the western part of House I, was made from the same tree as Post 962, sample B-125.

\section{B-127. Seeberg Burgäschisee-Süd 14 Future: $120 \pm 80$}

Tree-wood (Fraxinus), coll. November 1957. Young tree, cut in summer 1957 at the site of the excavation; sample taken from tree rings 1953-1957. Comment: presumably, as a result of $\mathrm{C}^{14}$ production by atomic tests, the sample has more $\mathrm{C}^{14}$ than our modern reference, corresponding to a slightly negative or "future" age.

\section{REFERENCES}

Bandi, H. G., 1952, Ur- und Frühgeschichtliche Fundstationen des Kantons Bern, Paleolithikum: Bern. Hist. Mus. Jahrb., v. 3 (1951), p. 104-108, illus.

Beck, P., 1938, Bericht über die ausserordentliche Frühjahrsversammlung der Schweiz. Geol. Gesellschaft in Thun 1938: Eclogae geol. Helvetiae, v. 31, p. 173-198, illus.

Ferrara, G., Reinharz, M., and Tongiorgi, E., Carbon-14 dating in Pisa: Am. Jour. Sci. Radioc. Supp., v. 1, p. 103-110.

Gerber, Ed., 1923, Die Schieferkohlenlager im Glütschtal: Die diluvialen Schieferkohlen der Schweiz: Beitr. geol. Schweiz, Geotech. ser. 8, p. 30-101.

Guyan, W., 1955, Das jungsteinzeitliche Moordorf von Thayingen-Weier: Das Pfahlbauproblem, Basel.

Houtermans, F. G., and Oeschger, H., 1958, Proportionalzählrohr zur Messung schwacher Aktivitäten weicher $\beta$-Strahlung: Helvetica Phys. Acta, v. 31, p. 117-126.

Lüdi, Werner, 1934, Das Alter des Uto-Mergels und seiner Hölzer: Naturf. Gesell. Zürich, Jahrg. 79 , no. 1-3, p. 156-168.

1953, Die Pflanzenwelt des Eiszeitalters im nördlichen Vorland der Schweizeralpen: Geobot. Inst. Rübel, Zürich, Veröffentl., no. 27, 208 p., illus.

Münnich, K. O., 1957, Heidelberg natural radiocarbon measurements I: Science, v. 126, p. 194-199.

Röthlisberger, H., and Oeschger, H., in press, Datierung eines ehemaligen Standes des Aletschgletschers durch Radioaktivitätsmessung an Holzproben und Bemerkungen zu Holzfunden an weiteren Gletschern: Zeitschr. Gletscherkunde u. Glaziologie.

Rytz, W., 1923, Die Pflanzenwelt der Schieferkohlen von Gondiswil-Zell: Beitr. geol. Schweiz, Geotech. ser. 8, p. 79-101.

Vries, Hessel de, and Barendsen, G. W., 1954, Measurements of age by the Carbon-14 technique: Nature, v. 174, p. 1138-1141.

Wegmüller, S., in press, Pollenprofil Hohgant: Naturf. Gesell. Bern Mitt.

Welten, Max, 1952, Ueber die spät- und postglaziale Vegetationsgeschichte des Simmentals, sowie die frühgeschichtliche und historische Wald- und Weiderodung auf Grund pollenanalytischer Untersuchungen: Geobot. Inst. Rübel, Zürich, Veröffentl., no. 26, 135 p., illus.

1958a, Pollenanalytische Untersuchungen alpiner Bodenprofile: Geobot. Inst. Rübel, Zürich, Veröffentl., no. 33, p. 253-274. 
1958b, Die spätglaziale und postglaziale Vegetationsentwicklung der BernerAlpen und -Voralpen und des Walliser Haupttales (mit $\mathrm{C}_{14}$-Alytersbestimmungen) : Geobot. Inst. Rübel, Zürich, Veröffentl., no. 34, p. 150-158.

Wyss, R., 1953, Beiträge zur Typologie der paleolithischen/mesolithischen Uebergangsformen im Schweiz Mittelland. Mit besonderer Berücksichtigung der Freilandstation Fürsteiner: Insts. f. Ur- und Frühgeschichte Schweiz Schr., no. 9, 124 p., illus. 